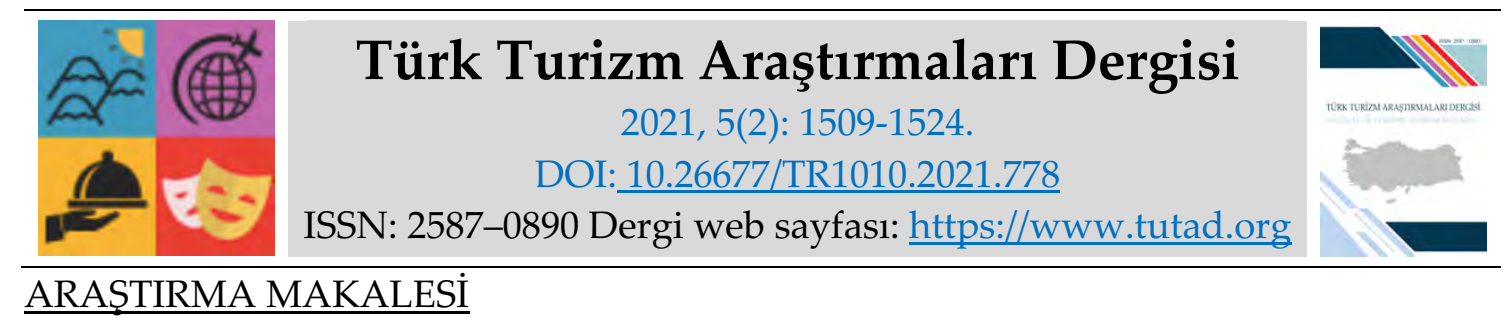

\title{
Küçük ve Orta Ölçekli Otel İşletmelerinin Banka Kredi Limitlerinin Revizesinde Kredi Tahsis Ön Değerlendirme Kriterlerinin Önemi: AHP Analizi
}

Dr. Öğr. Üyesi Filiz YETiZ, Akdeniz Üniversitesi, Uygulamalı Bilimler Fakültesi, Antalya, eposta: filizyetiz@akdeniz.edu.tr

ORCID: https://orcid.org/0000-0001-5480-9268

Doç. Dr. Burcu ILGAZ, Akdeniz Üniversitesi, Manavgat Meslek Yüksekokulu, Antalya, e-posta: burcuilgaz@akdeniz.edu.tr ORCID: https://orcid.org/0000-0001-5722-5196

\section{Öz}

Kredi işlemlerinin başlaması aşamasından kredi limitlerinin oluşturulmasına kadar olan süreç kredi tahsis açısından oldukça önemlidir. Kredi tahsis sürecinde müşterinin iyi araştırılması ve mali verilerinin derinlemesine incelenmesi gerekir. Bu amaçla bankalarda kredi tahsis yetkilileri tarafından değerlendirme kriterleri ile ön inceleme yapılmaktadır. Bu çalışmanın amacı, bankaların küçük ve orta ölçekteki otel işletmelerinin kredi limitlerinin revizesinde bir diğer ifadeyle yeniden kredi limitleri oluşturulurken tahsis aşamasında göz önünde bulundurdukları kriterlerin neler olduğunun açıklanması ve bu kriterlerin önem derecesinin belirlenmesidir. Çalışmada müşteri ön kontrol, finansal yapı, istihbarat ile kurumsal kimlik ve yönetsel yapı olmak üzere dört temel kriter ve bu temel kriterlere ait 26 alt kriterle değerlendirme gerçekleştirilmiştir. Kriterlerin seçiminde kredi tahsis bölümünde uzun süre çalışmış ve çalışmakta olan yetkililerin görüşlerinden ve literatür çalışmalarından faydalanılmıştır. Kredi tahsis aşamasında yararlanılan tahsis ön değerlendirme kriterleri sayesinde bankalar firmaların ihtiyacı kadar kredi limitini uygun teminat koşulları ile sağlamaktadır. Değerlendirme kriterlerinin tahsisteki diğer bir önemi ise ne kadarlık bir kredi riskinin finanse edilmesi gerektiği konusunda banka kredi tahsis birimindeki yetkililere aydınlatııı bilgiler sunmasıdır. Bu bağlamda kredi tahsisi ön değerlendirme kriterlerinin önem düzeylerinin belirlenmesi için Analitik Hiyerarşi Prosesi (AHP) yöntemi kullanılmıştır. Analiz sonucunda küu̧ük ve orta ölçekli otel işletmelerinin kredilerinin revizesinde kredi tahsisi ön değerlendirme ana kriterlerinin önem sırası; finansal yapı, müşteri ön kontrol, istihbarat, kurumsal kimlik ve yönetsel yapı olarak tespit edilmiştir. Çalışmadan elde edilen sonuçlar, bankaların müşterilerine kredi limiti oluştururken daha çok hangi kriterleri ön planda tuttukları konusunda önemli bilgiler içermektedir.

Anahtar Kelimeler: Küçük ve Orta Ölçekteki Otel İ̧̧letmeleri, Krediler, Kredi Tahsis, Çok Kriterli Karar Verme, AHP Yöntemi.

Makale Gönderme Tarihi: 26.02.2021

Makale Kabul Tarihi: 03.06.2021

\footnotetext{
Önerilen Atıf:

Yetiz, F. ve Ilgaz, B. (2021). Küçük ve Orta Ölçekli Otel İşletmelerinin Banka Kredi Limitlerinin Revizesinde Kredi Tahsis Ön Değerlendirme Kriterlerinin Önemi: AHP Analizi, Türk Turizm Araştırmaları Dergisi, 5(2): 1509-1524.

(C) 2021 Türk Turizm Araştırmaları Dergisi.
} 


\title{
Journal of Turkish Tourism Research
2021, 5(2): 1509-1524.
DOI: 10.26677/TR1010.2021.778 \\ RESEARCH PAPER
}

\section{Importance of Credit Allocation Pre-Evaluation Criteria in The Revision of Bank Credit Limits of Small and Medium-Sized Hotel Enterprises: AHP Analysis}

\author{
Assistant Prof. Dr. Filiz YETIZ, Akdeniz University, Faculty of Applied Sciences, Antalya, e-mail: \\ filizyetiz@akdeniz.edu.tr \\ ORCID: https://orcid.org/0000-0001-5480-9268
}

Associate Prof. Dr. Burcu ILGAZ, Akdeniz University, Manavgat Vocational School, Antalya, email: burcuilgaz@akdeniz.edu.tr ORCID: https://orcid.org/0000-0001-5722-5196

\begin{abstract}
The process from the start of credit transactions to the creation of credit limits is very important for credit allocation. In the credit allocation process, the customer needs to be well researched and their financial data examined in depth. For this purpose, pre-examination with evaluation criteria is carried out by credit allocation authorities in banks. The aim of this study is to explain what the criteria that banks consider during the allocation phase when re-creating credit limits in the revision of the credit limits of small and medium-sized hotel enterprises and to determine the importance of these criteria. In the study, evaluation was carried out with four basic criteria such as customer pre-control, financial structure, intelligence, corporate identity and administrative structure and sub-criteria of these basic criteria. In the selection of the criteria, the opinions and literature studies of the officials who worked and worked for a long time in the loan allocation department were used. Thanks to the allocation pre-evaluation criteria used during the loan allocation phase, banks meet the credit limit with appropriate collateral conditions as much as the companies need. Another important of the evaluation criteria in the allocation is that it provides enlightening information to the authorities in the bank's credit allocation unit about how much credit risk should be financed. In this context, the Analytical Hierarchy Process (AHP) method was used to determine the severity levels of the credit allocation pre-evaluation criteria. As a result of the analysis, the order of importance of the main criteria for pre-evaluation of credit allocation in the revision of loans of small and medium-sized hotel enterprises; financial structure, customer pre-check, intelligence, corporate identity and managerial structure. The results of the study contain important information about which criteria banks prioritize when creating credit limits for their customers.
\end{abstract}

Keywords: Small and Medium Hotel Businesses, Loans, Credit Allocation, Multi-Criteria Decision Making, AHP Method.

Received: 26.02 .2021

Accepted: 03.06.2021

Suggested Citation:

Yetiz, F. and Ilgaz, B. (2021). Importance of Credit Allocation Pre-Evaluation Criteria in The Revision of Bank Credit Limits of Small and Medium-Sized Hotel Enterprises: AHP Analysis, Journal of Turkish Tourism Research, 5(2): 1509-1524.

(C) 2021 Türk Turizm Araştırmaları Dergisi. 


\section{Gíriş}

KOBİ (Küçük ve Orta Ölçekli İşletmeler)'lerin tanımı ülkeden ülkeye değişiklik göstermekle birlikte net bir tanımı yoktur. Ülkemizde KOBİ'leri “250 kişiden az çalışan istihdam eden ve yıllık net satış hasılatı veya mali bilançosundan herhangi biri 125 milyon Türk Lirasını aşmayan ve mikro işletme (1-9 çalışan), küçük işletme (10-49 çalışan) ve orta büyüklükteki (50-249 çalışan) işletme olarak sınıflandırılabilen ekonomik birimler ve girişimler" şeklinde tanımlamak mümkündür (KOSGEB, 2018). KOBİ kapsamındaki otel işletmelerinin tanımı içinde bu kriterler önemlidir. Bir otel işletmesinin KOBI statüsünde yer aldığını anlamak için oda sayısı ya da oda kapasitesi gibi bilgilerden de yararlanılmaktadır. Küçük ve orta ölçekteki otel işletmeleri istihdam olanakları oluşturması, döviz gelirleri yaratması, yeni iş olanakları oluşturması, diğer sektörlerin gelişimine katkı sağlaması gibi pek çok açıdan ekonomik büyümeyi desteklemektedirler. Ekonomik açıdan önemli olan bu sektörlerin faaliyetlerine büyüyerek devam edebilmeleri için öz kaynakları dışında finansman ihtiyaçları uygun banka kredileri ile karşılanmalıdır. Küçük ve orta ölçekteki otel işletmeleri yeni yatırımlarını finanse etmek, işletme sermayesi ihtiyaçlarını karşılamak gibi nedenlerle de çalıştığı bankalardaki kredi limitini artırmak isteyebilir ya da mevcut limitlerle ancak daha az teminatla çalışmaya devam etmek için kredi limitlerinin ve tahsis şartlarının yeniden oluşturulmasını revize edilmesini isteyebilir.

İşletmelerin talep ettikleri yeni kredi limitlerine ilişkin kararların verilmesi, kredi talep sürecini hızlandırması kararları bankaların kredi tahsis bölümleri tarafından gerçekleştirilir. Kredi tahsis bölümünde görev yapan yetkililer, uzmanlar işletmelerin mali yapısını, piyasa istihbaratını, faaliyet konusu gibi kriterleri göz önünde bulundurarak kredi limitlerinin ve tahsis şartlarının yenilenmesine ya da eski limitlerle çalışmalarına devam etmesine yönelik kararlar verir. $\mathrm{Bu}$ bağlamda tahsis aşamasında değerlendirme kriterleri oldukça önemlidir. Çalışmada kredi tahsis sürecinde küçük ve orta ölçekteki otel işletmeleri kredi taleplerinin revizesinde veya yeniden kredi limiti veya tahsis şartlarının oluşturulması aşamasında tahsis sürecinde göz önünde bulundurulan ön değerlendirme kriterlerinin neler olduğunu ve bu kriterlerden hangilerinin kredi limiti oluşturulması aşamasında daha çok etkili olduğunu tartışılmaktadır.

Çalışmada, müşteri ön kontrol, istihbarat, finansal yapı, kurumsal kimlik ve yönetsel yapı olmak üzere dört temel kriter ile bu kriterlere ait alt kriterler bir bankanın kredi tahsis bölümünde uzun süre çalışmış ve çalışan yetkililer ile görüşmeler neticesinde seçilmiştir. Elde edilen bilgiler AHP (analitik hiyerarşi prosesi) yöntemi ile analiz edilmiş ve önem sırasına göre değerlendirmelerde bulunulmuştur. Çalışmanın amacı kredi tahsis sürecinde küçük ve orta ölçekteki otel işletmelerine kredi limiti oluşturulurken tahsis aşamasında hangi kriterlerin kredi değerlendirmelerinde ve kredi risk notu skorlamasında önemli olduğunu ortaya koymaktır. Değerlendirme kriterlerinin önem sırası hem kredi talep eden işletmeler hem de bankalar açısından dikkate alınmaktadır. Bankalar kredi limitlerini moralitesi iyi ve kredi ödeme ahlâkı düzgün, bankalarla çalışması problemsiz, piyasa istihbaratı olumlu, mali yapısı güçlü, sağlam teminat yapısına sahip işletmelere tahsis etmek isterler. Buna karar verilirken ise değerlendirme kriterleri ile işletmelerin kredi tahsisi gerçekleştirilir. Bazen işletmelere yeni kredi limitleri oluşturulur, bazen kredi limitleri artırılır bazen de kredi limit artışı veya kredi limitinin tahsis edilmesi uygun bulunmayabilir. Kredi tahsis yetkilisi ya da yöneticisi ön değerlendirme kriterleri ile kredi teklifinin banka kredi politikaları açısından uygun olduğunu tespit eder ve limitler bu şekilde oluşturulur veya oluşturulmaz. 


\section{BANKALARDA KREDİ TAHSİS ve ÖNEMİ}

Kredi tahsis, bankalarda kredi teklifinde bulunan müşterilerden temin edilen finansal olan ya da olmayan veriler, sektörel, politik, makro ekonomik ve küresel gelişmeler çerçevesinde, ilgili bankacılık kanuna, banka yönetmeliğine, politika ve teminatlarına bağlı kalarak, müşteriye en uygun krediyi vade ve sağlam teminat yapısıyla tesis edilmesi sürecidir (Yazıcı, 2010:24). Bankalar için krediler önemli bir gelir kaynağıdır. Bundan dolayı kredi taleplerini değerlendirilirken bankalar oldukça titiz ve dikkatli davranırlar. Kredi tahsis süreci kredi talebinde bulunan banka müşterisinin yerinde ziyaret edilmesi ile faaliyetlerinin gözlemlenmesi, tahsis aşamasında gerekli olan önemli evrakların temin edilmesi, ön kontrol incelemesinde müşterinin bankalarla yada sektördeki diğer müşterilerle çalışma biçiminin araştırılması, mali verilerinin doğru bir şekilde analiz edilmesi, piyasa istihbaratının dikkatli yapılmasının ardından tahsis komitesinde ilgili kredi talebinin değerlendirilmesiyle bir karara varılması aşamalarını kapsamaktadır.

Kredi tahsis aşamasında kredi teklifi yeni ve ilk kez çalışılacak bir müşteriye ait olabilir veya bankayla çalışması devam eden kredili müşterinin mevcut kredi limitlerini yeni teminat ve tahsis şartları ile revize etmek istediği bir teklif olabilir, ya da bankayla çalışması devam eden ama kredi limit artışı talebi ile teminat ve tahsis şartlarının revize edilmesi şeklinde bir kredi teklifi de olabilir. Kredi komitesi bankanın kredi politikaları yönetmeliği ve kredi tahsis ön değerlendirme kriterleri kapsamında müşterinin kredi talebini onaylayabilir, yeni limitler, yeni teminat koşulları ve tahsis şartları ile çalışılmasını uygun bulabilir. Komite kararı ile müşterinin eski limitlerle çalışılması da uygun bulanabilir veya komite kredi teklifini uygun bulmayıp ret edebilir.

Kredinin etkin biçimde verilmesi hem güvenilir hem de iyi tanımlanmış kredi verme kriterlerinin belirlenmesiyle oluşur. Bu kriterler, bankaların kredi faaliyetlerini verimli bir şekilde yürütebilmelerine olanak tanımaktadır. Bankalardan kredi almak isteyen kişi veya işletmeler, banka tarafından belirlenmiş bu kriterler ışığında incelemeye alınır ve yapılan değerlendirme sonucunda uygun bulunanlar kredilendirilir (Girginer, 2008: 133). Kredilendirme sürecinde özellikle müşterilerden talep edilen evraklarda eksiklik olmaması, müşterinin iyice tanınması değerlendirme kriterleri açısından oldukça önemlidir. Müşterilerden eksik bilgi ve evrakların alınması, istihbaratın dikkatli ve doğru yapılmaması kredi limitlerinin yanlış oluşturulmasına, teminatların yanlış belirlenmesi, kredi türünün, vadesinin, çalışma koşullarının hatalı oluşması sorunlarına yol açabilmektedir.

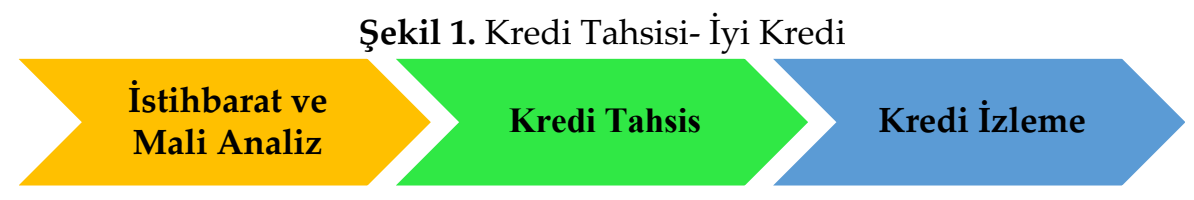

Kaynak: Kocameşe, 2006:43

Şekil 1'de belirtildiği üzere iyi kredi, istihbarat ve mali analizlerin kredi tahsis sürecinde dikkatli ve titiz bir şekilde yapılmasıyla ihtiyaca uygun kredi tahsisin gerçekleştirilmesi sonucunda oluşturulmaktadır. Kredi tahsisin titiz bir şekilde yapılması ile bankaların kredi risklerinden korunmasını sağlanarak krediler sorunsuz bir şekilde izlenebilecektir.

Ülkemize önemli döviz girdisi sağlayan turizm sektörünün gelişmesi için otel işletmelerinin yatırım ve finansman ihtiyacının karşılanması gerekir. Otel işletmelerinin finansman gereksinimi; ilk yatırım sırasında, mevcut tesislerinin genişletilmesi ve giderlerinin karşılanması aşamasında doğmaktadır (Küçükaltan ve Eskin, 2008:158 ve 161). Otel işletmelerinin finansman ihtiyaçlarını karşılamak için ağırlıklı olarak banka kredilerini kullandıkları söylenebilir 
(Karadeniz vd., 2018). Otel işletmelerinin finansman yapıları incelendiğinde, bu işletmelerin aktif yapılarının \% 90'ını Duran Varlıklardan, \% 10'nu Dönen Varlıklardan oluşmakta ve işletmenin kuruluş ile faaliyet aşamalarında sermayeye ihtiyaç duydukları sonucu ortaya çıkmaktadır (Çetiner, 2002:13-14). Ayrıca küçük ölçekli otel işletmelerinin yerel ekonomilerde istihdamı artırması, yabancı sermayeyi çekme ve kültürel gelişmeye yön vermesi açısından ekonomiye katkı sağlamaktadırlar. Bu sebeplerden dolayı finansman ihtiyaçlarının bir kısmı banka kredileri ile finanse edilmektedir. Küçük ve orta büyüklükteki bir otel işletmesinin için kredi teklifinin revizesinin değerlendirilmesi için birçok ön değerlendirme kriterin dikkate alınması gerekir. Bu sebeple çalışmada küçük ve orta ölçekteki otellere kredi tahsisi yapılmadan önce bankaların kredi tekliflerini değerlendirme süreçlerinde göz önüne aldıkları kriterler belirlenmiştir. Bu ana kriterler; "Müşteri Ön Kontrol Kriteri", "Otel İşletmesinin Finansal Yapısı" "Otel İşletmesinin Kurumsal Kimlik ve Yönetsel Yapı" ve "İstihbarat" olmak üzere 4 tanedir ve bunların alt kriterleri de çalışmada dikkate alınmıştır.

\section{LITERATÜR TARAMASI}

İşletmelerin kredi değerlendirme ve kredi tahsis sürecine yönelik literatür çalışmaları kronolojik olarak aşağıda özetlenmiştir.

Chen ve Chiou (1999), Tayvan ülkesi için yapmış oldukları çalışmalarında "Üçgen Bulamık Sayılar" yöntemini kullanmışlardır. Değerlendirme kriteri olarak finansal oranlar, karakter ve yönetim şartları değişkenleriyle kredi değerlendirmesi yapmışlardır. Elde edilen sonuçlar kredi yetkililerine kredi değerlendirmede önemli bilgiler sunmuştur.

İç ve Yurdakul (2000) çalışmalarında AHP (Analitik Hiyerarşi Prosesi) metodu ile bankalar için bir kredi değerlendirme model önerisi geliştirilmiştir. Firmaların "subjektif kredi değerliliği, faaliyet gösterdikleri sektörün durumu ve kredi teminatları" gibi nitel ve nicel faktörler dikkate alınmıştır. Bankacılıkta kredi işlevinin iyileştirilmesine ve pratikleşmesine yönelik olarak oluşturulan öneri modelinin aynı zamanda diğer sektörlerde de uygulanarak kapsamının genişletilebileceği vurgulanmıştır.

Sekreter vd., (2004) çalışmalarında AHP yöntemini kullanarak Türkiye'de İMKB'de işlem gören gıda sektöründeki firmaların kredibilitelerinin derecelendirilmesine yönelik bir inceleme yapmışlardır. Yöntemde likidite, faaliyet, mali yapı, büyüme ve kârlılık oranı kriterleri kullanılmıştır. Çalışma sonucunda geliştirdikleri model ile borsada işlem gören gıda firmalarının birbirleri ile belirlenen kriterler ve öncelikler doğrultusunda sayısal olarak karşılaştırılabilmişlerdir.

Atan ve Maden (2005), Türkiye üzerine yapmış oldukları çalışmalarında moralite, kredi kayıt bürosu ekran sonuçları, kefil, gelir durumu, iş durumu, mal varlığı, kişisel bilgi kriterleri ve 20 alt kriter seçilmiştir. Bu değerlendirme kriterleri AHP yöntemi ile incelenmiştir. Analizden elde edilen bilgiler bankalara bireysel ve kurumsal müşterilere kredi vermek veya vermemek konusunda değerlendirme yapma seçeneğini sunmaktadır.

Girginer (2008) çalışmasında AHP yöntemi ile kamu ve özel bankaların ticari kredi taleplerini incelemede dikkate aldıkları kriterler ve bu kriterlerin ağırlıklarını değerlendirmiştir. Mali, yönetsel, sektörel ve istihbarat kriterleri Ticari kredi başvurularının değerlendirmesinde kamu bankasının en çok firmanın mali yapısına, özel bankanın ise yönetsel yapı ve istihbarata önem verdiği sonucuna ulaşılmıştır. 
Aouam vd., (2009), Fas ülkesi incelenmiş ve çalışmalarında AHP ve DA (Ayrımcılık Analizi) yöntemleri tercih edilmiştir. Kalitatif ve kantitatif değerlendirme kriterleri yardımıyla Fas Kalkınma bankasında gerçek bir vaka çalışması kullanılmış, uygulanmış ve doğrulanmıştır. Oluşturulan model sayesinde kredinin verilip verilmeyeceği konusunda kredi karar vericilere bir alternatif sunulmuştur.

Akkaya ve Demireli (2010) çalışmalarında AHP sürecini kullanarak kredilendirme sürecine ilişkin bir derecelendirme modeli oluşturmuşlardır. Türkiye için yapılan çalışmada likidite, kârlılık, devir hızı oranları, ekonomik yapı, finansal yapı ve bunların 24 alt kriterleri dikkate alınmıştır. Çalışma sonucunda kredi kuruluşlarının kredilendirme sürecinde kriterler içinde en fazla faaliyet devir hızlarını göz önünde bulundurdukları, finansal yapı oranlarının ise en az öneme sahip olduğu belirtilmiştir.

Erpolat (2011) çalışmasında AHP ve farklı bulanık sıralama yöntemlerini kullanarak aynı sektörde faaliyet gösteren iki işletmenin ticari kredi taleplerinin değerlendirilmesinde bankalara yol gösterebilecek bir uygulama geliştirmiştir.

Saardchom (2012) AHP yöntemi bankalarda konut kredisi taleplerinin değerlendirilmesini araştırmıştır.

Ferreira vd., (2014) Portekiz ülkesi özelinde yapmış oldukları çalışmalarında AHP yöntemini kullanmışlardır. Mortage kredileri için 14 risk değerlendirme kriteri (meslek, yaş, medeniyet durumu, ülkenin ekonomik durumu, vb.) seçilmiştir. Çalışma sonucu da benzer yöntemlerle kıyaslama yapılmış önerilerde bulunulmuş̧tur.

Büyükçelebi ve Coşkun (2015) Türkiye'de kredi taleplerinin değerlendirilmesi aşaması analitik hiyerarşi süreci yaklaşımı ile incelenmiştir. AHP yönteminde, finansal yapı, sektör durumu, yönetim ve ortak yapısı, firma ve istihbarat kriterleri ile bunların alt kriterleri kullanılmıştır. Katılım ve mevduat bankalarının karşılaştırıldığı çalışmada ticari kredi değerlendirme sürecinde her ikisinde de en önemli değerlendirme ana kriterinin istihbarat verileri olduğu tespit edilmiştir.

Pekkaya ve Zilifli (2016) çalışmalarında KOBİ ve Ticari işletmelerin kredi taleplerinin değerlendirilmesi sürecinde dikkate alınan kriterlerin önem dereceleri AHP metodu ile belirlenmeye çalışılmıştır. 7 ana kriter için değerlendirme yapılan çalışmada firmalara kredi vermede kriterlerden sırasıyla iş hacmi-karlılık, istikrar-istihbarat, teminat-mal varlığ kriterlerinin en çok önemli olan kriterlerden olduğu tespit edilmiştir.

Karakış ve Göktolga (2017) AHP ve TOPSIS yöntemlerinin ticari kredi taleplerinin değerlendirilmesinde uygulanabilirliği araştırılmıştır. Kredi taleplerinin değerlendirilmesinde firmanın mali tablolar analizi, firma ortak ve yöneticilerinin moralitesi, firma kapasitesi ve borç ödeme performansı, sektörün ekonomik görünümü, kredi teminatları ve teminat yapısı gibi ana kriterler ve bunların alt kriterleri belirlenmiştir. Çalışmada firmaların kredi taleplerinin değerlendirilmesinde en etkili kriterin firma kapasitesi ile borç ödeme performansı ana kriteri olduğu, bu kriterleri önem ağırlığı ile kredi teminatları ve teminat yapısı kriterlerinin izlediği sonucuna ulaşılmıştır.

Hosseini ve Keshavarz (2017), çalışmalarında özel, kamu bankası, yarı özel banka gibi bankaların hizmet kalitesi faktörleri ve maddi değerler, güvenilirlik, bilgi kalitesi, profesyonellik gibi alt ölçütlerine göre sıralanmıştır. Bulanık analitik hiyerarşi süreci (FAHP) ve bulanık TOPSIS kullanarak bankacılık endüstrisi değerlendirilmiştir. Her iki yöntemden elde edilen sonuçlar, bankacılık sektöründe özel bankanın yarı özel banka ve devlet bankasından daha önemli olduğunu göstermiştir. 
Eren vd., (2020), bankaların otel işletmelerinin kredi taleplerini değerlendirirken hangi kriterleri dikkate aldıklarını ve bunların önem derecelerine göre sıralamalarını belirlemek için AHP ve TOPSIS yöntemi kullanılmıştır. Analizde 4 ana kriter; otel işletmesinin finansal yapısı, kurumsal ve yönetsel yapısı, sektörel yapısı ve otel işletmesi ile ilgili istihbarat ve bunlara ait alt kriterler seçilmiştir. Elde edilen kriterlerin önem düzeyleri AHS yöntemi ile tespit edilmiştir. Modelin test edilmesi için seçilen kriterler ve ağırlıkları dikkate alınarak kredi talep eden 10 adet otel işletmesinin kredi başvuruları TOPSIS yönteminden yararlanılarak sıralaması yapılmıştır. Banka açısından, en önemli ana kriterin finansal yapı olduğu sonucuna ulaşılmıştır.

Fernando ve Siagian (2020) çalışmalarında, AHP yöntemi kullanılarak bir analiz önerilmektedir. Kredi analizi değerlendirmesinde 5C prensipleri tercih edilir (Karakter, Kapasite, Sermaye, Ekonomi Koşulları, Teminat). AHP Yöntemi kullanılarak yapılan karar analizinin sonuçları, muhtemel bir borçlunun gereklilikleri karşılayıp karşılamayacağını beyan etmede doğru ve doğru kararın belirlenmesinde ölçütlerdir. $\mathrm{Bu}$, memnuniyeti artırmaya ve tüketicilere en iyi hizmeti sunmaya yardımcı olmaktadır.

Literatür araştırmaları incelendiğinde turizm işletmelerine yönelik çalışma sayısının literatürde oldukça sınırlı olduğu görülmektedir. Türk Bankacılık sektörü için yapılan çalışmalarda İç ve Yurdakul, 2000; Sekreter vd., 2004; Atan ve Maden, 2005; Girginer, 2008; Akkaya ve Demireli, 2010; Büyükçelebi ve Coşkun 2015; Pekkaya ve Zilifli, 2016, kredi taleplerinin değerlendirilmesinde sadece AHP yöntemini kullanmıştır. Diğer ülkeler için yapılan çalışmaların bir kısmında kredi değerlendirme sürecinde hem AHP hem de farklı yöntemlerle değerlendirmeler ele alınmıştır. (Chen ve Chiou, 1999; Aouam vd., 2009; Ferreira vd., 2014). Literatürde bankaların kredi değerlendirme süreçlerinin araştııılmasında çok kriterli karar verme yöntemlerinden AHP yönteminin ağırlıklı olarak tercih edildiği görülmektedir.

\section{YÖNTEM}

Çalışmada küçük ve orta ölçekli otel işletmelerinin banka kredi limitlerinin revizesinde kredi tahsis ön değerlendirme kriterlerinin belirlenmesi için, literatür taraması ve alanında uzun süre çalışmış ve çalışmakta olan tecrübeli kredi tahsis yetkilileri görüşlerine başvurulmuştur. Yöntem olarak AHP (Analitik Hiyerarşi Prosesi) ile kriterler ve ağırlıkları belirlenmiştir. Bu yöntem, nicel verilerin nitel verilere dönüşmesini sağlamaktadır. Yöntem kredi tahsis yetkililerinin görüşüne göre belirlenmekte, her bir kriter için 1-9 aralığında tahsis yetkilileri tarafından değerlendirme gerçekleştirilecektir. AHP yönteminde ilk aşamada ana kriterlerin ağırlıkları belirlenmekte, ikinci aşamada ise ana kriterlerin her birinin alt kriterinin ağırlığı tespit edilecektir.

\section{Kriterlerin Belirlenmesi}

Analiz yönteminde kullanılan tahsis ön değerlendirme kriterleri belirlenirken literatürdeki çalışmalar ve Adana'da örnek bir bankada tahsis biriminde görev yapmış ve yapan yetkililerden elde edilen bilgiler çerçevesinde elde edilmiştir. Çalışmada seçilen kriterlerin belirlenmesi aşamasında örnek bir bankanın Adana Bölge Koordinatörlüğü Kredi Tahsis ve Yönetimi bölümünde görev yapan üç yönetmen, daha önce bu bölümde çalışmış 1 kıdemli uzman ve 1 yönetmen görüşüşünden yararlanılmıştır. Çalışmaya katkı sağlayan kredi tahsis yetkilileri bankanın tahsis biriminde uzun süre çalışmış ve hatta bankanın farklı birimlerinde de çalışmış alanında tecrübeli kişilerden oluşmaktadır. Literatür araştırması ve kredi tahsis yetkilileri ile görüşmeler neticesinde "Müşteri Ön Kontrol", "Finansal Yapı", "İstihbarat", "Kurumsal Kimlik ve Yönetsel Yapı" olmak üzere dört temel kriter ile bu kriterlere ait 26 alt kriter elde edilmiştir. Literatür araştırmalarından ise ana kriterlerin belirlenmesinde Girginer (2008), Büyükçelebi ve 
Coşkun (2015), Karakış ve Göktolga (2017) ve Eren, Ilgaz ve Karapınar (2020) çalışmalarından faydalanılmıştır. Tablo 2'de kredi tahsis ön değerlendirme kriterleri detaylı bir şekilde belirtilmiştir.

Tablo 2. Küçük ve Orta Ölçekli Otel İşletmelerinin Kredi Revizesinde Tahsis Ön Değerlendirme Kriterleri

\begin{tabular}{|c|c|c|c|}
\hline \multicolumn{4}{|c|}{ KOBİ Segmentindeki Otel İşletmelerinin Kredi Revizesi-Ana ve Alt Kriterler } \\
\hline Müşteri Ön Kontrol & Finansal Yapı & $\begin{array}{l}\text { Kurumsal Kimlik } \\
\text { ve Yönetsel Yapı }\end{array}$ & İstihbarat \\
\hline $\begin{array}{l}\text { Firma yetkilerinin } \\
\text { moralite sorgulaması } \\
\text { (Karakış ve Göktolga, } \\
\text { 2017) }\end{array}$ & $\begin{array}{l}\text { Özsermaye yapisı } \\
\text { (Girginer, 2008) }\end{array}$ & $\begin{array}{l}\text { Firmanın } \\
\text { sektördeki faaliyet } \\
\text { süresi (Büyükçelebi } \\
\text { ve Coşkun, 2015) }\end{array}$ & $\begin{array}{l}\text { İşletme müşterilerinden } \\
\text { istihbarat (Girginer, } \\
2008 \text { ) }\end{array}$ \\
\hline $\begin{array}{l}\text { Firma ortaklarının } \\
\text { moralite sorgulaması } \\
\text { (Karakış ve Göktolga, } \\
\text { 2017) }\end{array}$ & $\begin{array}{l}\text { Likidite yapısı } \\
\text { (Karakış ve } \\
\text { Göktolga, 2017) }\end{array}$ & $\begin{array}{l}\text { Firma } \\
\text { yöneticilerinin } \\
\text { sektör deneyimi } \\
\text { (Karakış ve } \\
\text { Göktolga, 2017) }\end{array}$ & $\begin{array}{l}\text { Satıcılardan elde edilen } \\
\text { istihbarat (Girginer, } \\
\text { 2008) }\end{array}$ \\
\hline $\begin{array}{l}\text { Firmanın kuruluşundan } \\
\text { günümüze faaliyet } \\
\text { konusunun devamlıllığ }) \\
\text { (Tahsis yetkilisi görüşü) }\end{array}$ & $\begin{array}{l}\text { Net satışlardaki } \\
\text { değişim (Tahsis } \\
\text { yetkilisi görüşü) }\end{array}$ & $\begin{array}{lr}\text { Firma } & \text { ortaklarının } \\
\text { sektör } & \text { deneyimi } \\
\text { (Karakış } & \text { ve } \\
\text { Göktolga, 2017) }\end{array}$ & $\begin{array}{l}\text { Sektördeki rakip } \\
\text { firmalardan istihbarat } \\
\text { (Büyükçelebi ve } \\
\text { Coşkun,2015) }\end{array}$ \\
\hline $\begin{array}{l}\text { TCMB memzuç bilgisi } \\
\text { (limit-risk-kanuni takip) } \\
\text { (Tahsis yetkilisi görüşü) }\end{array}$ & $\begin{array}{lr}\text { Kisa } & \text { vadeli } \\
\text { Borç/Toplam Borç } \\
\text { Yapisı (Girginer, } \\
\text { 2008) }\end{array}$ & $\begin{array}{lr}\begin{array}{l}\text { Firmanın } \\
\text { yapısı) }\end{array} & \text { ortaklık } \\
\text { (Tahsis }\end{array}$ & $\begin{array}{l}\text { Çalıştığı bankalardan } \\
\text { istihbarat (Büyükçelebi } \\
\text { ve Coşkun,2015) }\end{array}$ \\
\hline $\begin{array}{l}\text { İcra, haciz, vergi borcu } \\
\text { olup olmamas1 (Tahsis } \\
\text { yetkilisi görüşü) }\end{array}$ & $\begin{array}{l}\text { Dönem net kârı } \\
\text { (Akkaya ve } \\
\text { Demireli,2010) }\end{array}$ & $\begin{array}{l}\text { Firmanın personel } \\
\text { sayıs1 } \\
\text { ve }\end{array}$ & $\begin{array}{l}\text { Sektörün ekonomik } \\
\begin{array}{l}\text { yapısı (Karakış ve } \\
\text { Göktolga, 2017) }\end{array}\end{array}$ \\
\hline $\begin{array}{l}\text { TCMB Karşılıksız çek } \\
\text { kayıtları (Tahsis yetkilisi } \\
\text { görüşü) }\end{array}$ & $\begin{array}{l}\text { Stoklardaki } \\
\text { değişim (Tahsis } \\
\text { yetkilisi görüşü) }\end{array}$ & $\begin{array}{l}\text { İşletmenin } \\
\text { mülkiyet durumu } \\
\text { (Eren, Ilgaz ve } \\
\text { Karapınar, (2020) }\end{array}$ & $\begin{array}{lr}\text { Kredi } & \text { talebinde } \\
\text { bulunan müşterinin } \\
\text { ziyareti (Tahsis yetkilisi } \\
\text { görüşü) }\end{array}$ \\
\hline $\begin{array}{l}\text { TCMB Protestolu senet } \\
\text { kayıtları (Tahsis yetkilisi } \\
\text { görüşü) }\end{array}$ & & $\begin{array}{l}\text { Teminat durumu } \\
\text { (Pekkaya ve Zilifli, } \\
\text { 2011) }\end{array}$ & \\
\hline
\end{tabular}

\section{Müşteri Ön Kontrol Ana Kriteri}

$\mathrm{Bu}$ kriterin alt kriterleri; firma yetkilileri ve ortakların moralitesi, işletmenin kuruluşundan günümüze faaliyet konusunun devamlılı̆̆ı, TCMB (Türkiye Cumhuriyet Merkez Bankası) memzuç bilgisi, TCMB karşılıksız çek ve protestolu senet bilgisi, icra, haciz, vergi borcu sorgulama kriterleridir. Tahsis yetkilisi tahsis öncesi sorgulama yaparken, kredi limiti revize edilecek küçük ve orta ölçekli otel işletmesinin yetkilileri ve ortakların bankalarla olan çalışma geçmişi incelenip moralitesi araştırılır. Ayrıca otel işletmesinin kuruluşundan günümüze faaliyet konusunun devamlılığını anlamak için ticaret sicil gazetelerinden incelemeler yapılır. TCMB memzuç bilgisinden ise otel işletmesinin diğer bankalardaki nakit veya gayri nakit toplam kredi limitleri, toplam kredi riski, çalıştığı banka sayısı gibi bilgiler elde edilmektedir. İcra, haciz ve 
vergi borcu sorgulama ekranlarında varsa bir olumsuzluk kredi limiti oluşturulmadan gerekli borçların ödenmesi ve icra ya da haczin kalktı̆̆ına dair belgelerin temin edilmesi gerekir. Ön kontrol sorgusu sırasında otel işletmesinin karşılıksız çek veya protestolu senet bilgilerine rastlanır ise bunlara ait düzelmesi yapılmış bilgi ve belgeler temin edilmeli aksi halde kredinin revizesi olumsuz sonuçlanabilir.

\section{Finansal Yapı Ana Kriteri}

Finansal yapı ile mali tablo hesap kalemleri arasında ilişki kurulması, ölçülmesi ve yorumlanması ile işletmenin mevcut finansal yapısının değerlendirilmesi, geleceğe yönelik kararlarında, bankaların özellikle dikkate aldığı önemli bir kriterden biridir. Finansal oranlar küçük ve orta ölçekli işletmenin likidite yeterliliğini, borç ödeyebilme gücünü, kârlılık yapısını ve verimliliğini göstermektedir (Büyükçelebi ve Coşkun, 2015:1010) Küçük ve orta ölçekli otel işletmesinin finansal yapısı incelenirken alt kriterler olarak özellikle bu çalışmada işletmenin öz sermaye yeterliliği, likidite yapısı, net satışların yıllar veya dönemler itibariyle artış ya da azalışı bilgisi, kısa vadeli borçların toplam borçların içindeki dağılımı, kârlılık ve stoklardaki değişimdir. Finansal yapısı güçlü olan otel işletmesi bankalarda daha düşük teminat karşılığında daha iyi kredi limitleri ile çalışma imkânı sağlamaktadır.

\section{Kurumsal Kimlik ve Yönetsel Yapı Ana Kriteri:}

Küçük ve orta ölçekli otel işletmesinin sektördeki faaliyet süresi, firma yöneticileri ve ortaklarının sektördeki deneyimleri, ortaklık yapısı, personel sayısı, işletmenin mülkiyet durumu ve teminat durumu alt kriterler olarak değerlendirilmişlerdir. İşletmenin faaliyet süresinin uzun olması sektör deki pazar gücünü faaliyetlerindeki devamlılı̆g işletmenin geleceği hakkında olumlu bilgiler içermektedir. İşletmelerin ortaklarının ve yöneticilerin sektör deneyimi küçük ve orta ölçekli otel işletmenin ilerde yapacağı yatırımlarda ve büyüme kararlarında profesyonel projelerde yer alırken bu alandaki deneyimlerden yararlanabileceklerini göstermektedir. Otel işletmenin tecrübeli ve yeterli sayıda personel sayısı ile hizmet vermesi ve faaliyetlerin yürütüldüğü otel işletmesinin mülkiyetinin kendisine ait olması bankalar için işletmenin kredi limiti revizesi talebinin onaylanması için hem güçlü teminatla çalışabilmesi hem de bankalara borcunu geri ödemesini kolaylaştırıcı bir durum olarak değerlendirilmektedir. Otel işletmesi ortaklarının mal varlığı ve otel işletmesinin kendisi banka kredilerinde limitlerin yenilenmesinde teminat kısmını oluşturması açısından önemlidir.

\section{İstihbarat Ana Kriteri}

Kredilendirme sürecinde bankalar ve banka dışı yerlerden sağlanan istihbaratla yapılmaktadır. İstihbaratta, mevcut ya da muhtemel müşteriler ile iş ilişkisi içerisinde bulunulan diğer kişilerin kimliği ile mal varlığı, ticari ahlâk ve alışkanlıklarını gerçeğe uygun bir şekilde tespit ederek piyasayı tanımak ve öngörülen riskleri kontrol etmek ile bilgi toplama faaliyetini anlatan bir kavramdır. İstihbarat kredi talep eden müşterinin krediyi zamanında geri ödeme yeteneği olup olmadığını araştırmaya yönelik yapılmaktadır. Bu açıdan müşterilerden veya satıcılardan yapılabilmektedir. (Girginer, 2008:136). Otel İşletmesi için istihbarat sürecinde satıcılardan elde edilen istihbarat, sektördeki rakip firmalardan istihbarat, işletmenin çalıştığı bankalardan istihbarat, sektörün ekonomik yapısı, kredi talebinde bulunan müşterinin ziyareti alt kriterler olarak dikkate alınmıştır. Kredi talep eden otel işletmesinin ekonomik yapısı incelendiğinde turizmin gelişimi, turizm sektöründeki finansal sorunlar, turizm geliştirme politikaları ile bu sektörün geleceği hakkında bilgilere sahip olunmaktadır. Bankalarda bu gelişime paralel olarak kredi limitlerini artırıp azaltma kararı verebilir. Kredilerin geri ödenmesinde sorun yaşanıp yaşanmayacağ bilgilere göre oluşturulur. Kredi talebinde bulunan müşterin ziyarete edilmesi tahsis açısından 
önemlidir. Müşteri ziyareti pazarlama bölümü yetkilileri, kredi talep eden otel işletmesinin müşteri temsilcisi, şube müdürü, bölge müdürü ve bazen de kredi tahsis yetkilisinin de katılımı ile gerçekleştirilir. Buradaki amaç eksik evrakların temin edilmesi, müşteri ön kontrol sorgusundan ortaya çıan olumsuzluklar hakkında bilgi ve belge temin etme, işletmenin faaliyetlerine devam ettiğini görebilme, işletmenin konumlandığı yeri yerinde ziyaret etme ve gerçekten böyle bir otel işletmesinin olduğunu anlama, mali verilere yansıyan veya yansımayan yönleri ortaklar ya da yöneticilerle konuşarak teyit etme, işletmenin gelecek iş planları hakkında bilgilere sahip olma işletmeyi yakından tanıyarak gerçek kredi limiti ihtiyacını öngörmek için gerçekleştirilir.

Bankalar küçük ve orta ölçekli otel işletmelerinin kredi limitlerini revize ederken müşteri ön kontrol sorgusunda moralitesi sorunsuz olan bankalarla çalışmasında kredi ödemeleri düzenli ve bankalarla çalışması problemsiz olan, mali verilerde finansal yapısı güçlü, piyasa istihbaratı sağlam olan otel işletmeleri için tahsis sorunsuz gerçekleştirilir. Bu değerlendirme kriterleri ile işletmelere yeni kredi limitleri oluşturulur, bazen kredi limitleri artırılır. Bazen de eğer tüm ana ve alt kriterlerde sorun var ise kredi riskli görüldügüunden kredi teklifi uygun bulunmaz. Küçük ve orta ölçekli işletmeler açısından ise değerlendirme kriterleri baz alınarak eksiklikler giderilmekte, tespit edilen moralite olumsuzlukları ile örneğin devlete ödenmeyen bir vergi borcu, karşllıksız çıkan bir çek, gecikmiş bir kredi borcu ya da takip var ise bu olumsuzluklara ilgili düzeltilmeleri yapıp gecikmiş borçlar, karşılıksız çekle ilgili gerekli düzeltme aksiyonları aldığında talep ettiği kredi limitini bankalardan kolayca oluşturabilir ve kredi teklifi ret edilmez. Ayrıca değerlendirme kriterlerini dikkate alarak eksik olduğu finansal alanları güçlendirir ise bankalarla daha az teminatla ama daha yüksek bir kredi limitiyle çalışma fırsatı yakalamış olur, böylece kredi limiti daha iyi şartlarla revize edilmiş olur.

\section{Kredi Revizesinde Bankaların Kredi Tahsis Ön Değerlendirme Kriter Ağırlıklarının Belirlenmesi: AHP Analizi}

Analitik Hiyerarşi Prosesi (AHP), ilk kez 1968 yılında Myres ve Alpert tarafından açıklanmış ve 1977 yılında Saaty tarafından bir model olarak geliştirilmiştir. Bu analiz yöntemi karmaşık karar problemlerinin çözüme kavuşturulmasında kullanılmaktadır (Yaralığlu, 2001: 131). AHP yönteminde kredi tahsis yetkililerinin görüşü ile her bir değerlendirme kriteri $1-9$ aralığında karşılaştırılmıştır. Bu analizin ilk aşamasında ikili karşılaştırma matrisleri ikinci aşamada ise kriterlerin önem derecesini görmek için matris oluşturulmuş, ardından matrislerin tutarlılık düzeyleri dikkatlice ölçülmüştür. Analiz işlemi ana ve alt kriterler olmak üzere iki aşamalı olarak gerçekleştirilmiştir. Analizden elde edilen sonuçlarla kriterlerin önem düzeyleri ortaya konmuştur. İkili karşılaştırmalarda kullanılan önem dereceleri ölçeği Tablo 3'de belirtilmiştir.

Tablo 3. AHP Analizi- Önem Dereceleri Ölçeği

\begin{tabular}{|c|l|l|}
\hline $\begin{array}{c}\text { Önem } \\
\text { Dereceleri }\end{array}$ & \multicolumn{1}{|c|}{ Tanımlar } & \multicolumn{1}{|c|}{ Açıklamalar } \\
\hline 1 & Aynı derecede öneme sahip & İkisi de aynı derecede önem taşımaktadır. \\
\hline 3 & Orta derecede öneme sahip & Biri diğerine göre orta düzeyde önem taşımaktadır. \\
\hline 5 & $\begin{array}{l}\text { Kuvvetli derecede öneme } \\
\text { sahip }\end{array}$ & Biri diğerine göre kuvvetli derecede öneme sahiptir. \\
\hline 7 & $\begin{array}{l}\text { Çok kuvvetli derecede } \\
\text { öneme sahip }\end{array}$ & Biri diğerine göre çok daha kuvvetli önem taşımaktadır. \\
\hline 9 & Aşırı derecede öneme sahip & Biri diğerine göre aşırı derecede önem taşımaktadır. \\
\hline $2,4,6,8$ & Ara değerler & Tercih değerleri birbirine yakın ise kullanılmaktadır. \\
\hline
\end{tabular}

Kaynak: Saaty, 1990:15. 
İkili karşılaştırma matrisi Tablo 4'te belirtildiği üzere, wi/wj terimi, i kriterinin j kriterine göre ne kadar önemli olduğunu işaret etmektedir. Eğer kriterin önem değeri 5 ise, i kriteri j kriterine göre daha kuvvetli düzeyde önemlidir ve $\mathrm{j}$ kriteri i kriterine göre $1 / 5$ düzeyinde önemlidir (Vargas, 1990).

Tablo 4. Kriterlere İlişkin İkili Karşılaştırma Matrisinin Oluşturulması

\begin{tabular}{|l|c|c|c|c|}
\hline & & Kriter 1 & Kriter 2 & Kriter..j \\
\hline Kriter 1 & $\mathrm{w}_{1} / \mathrm{w}_{1}$ & $\mathrm{w}_{1} / \mathrm{w}_{2}$ & $\mathrm{w}_{1} / \mathrm{wj}$ \\
\hline Kriter 2 & $\mathrm{w}_{2} / \mathrm{w}_{1}$ & $\mathrm{w}_{2} / \mathrm{w}_{2}$ & $\mathrm{w}_{2} / \mathrm{wj}$ \\
\hline Kriter..j & $\mathrm{wi} / \mathrm{w}_{1}$ & $\mathrm{wi}_{2} / \mathrm{w}_{2}$ & $\mathrm{wi} / \mathrm{wj}$ \\
\hline
\end{tabular}

Kaynak: Vargas, 1990: 4.

Kredi revizesi kredi tahsis ön değerlendirme kriterleri için ikili karşılaştırma matrisi oluşturmasının ardından önem matrisi oluşturulmaktadır. Bu matris her bir kriterin sütun toplamına kriter değerinin bölünmesi ile elde edilmektedir. İlgili sütunların ortalaması sonucunda edilen önem düzeyleri, nihai sıralama hakkında bilgi vermektedir. Söz konusu ana kriterlerin alt kriterlerinin nihai sıralaması ise, her bir kriterin önem düzeyinin alt kriterlerin önem düzeyle çarpılmasıyla hesaplanmaktadır.

AHP yönteminde, ikili karşılaştırma yargılarının tutarlılığı oldukça önemlidir. Tutarlık oranını ölçmek için çalışmada Saaty'ın önerdiği tutarlılık oranı dikkate alınmıştır. Tablo 5 'te rassal indeks göstergeleri yer almaktadır.

Tablo 5. Rassal İndeks (RI) Serisi Tablosu

\begin{tabular}{|c|c|c|c|c|c|c|c|c|c|c|c|c|c|c|c|}
\hline $\mathbf{N}$ & $\mathbf{1}$ & $\mathbf{2}$ & $\mathbf{3}$ & $\mathbf{4}$ & $\mathbf{5}$ & $\mathbf{6}$ & $\mathbf{7}$ & $\mathbf{8}$ & $\mathbf{9}$ & $\mathbf{1 0}$ & $\mathbf{1 1}$ & $\mathbf{1 2}$ & $\mathbf{1 3}$ & $\mathbf{1 4}$ & $\mathbf{1 5}$ \\
\hline $\mathrm{RI}$ & 0 & 0 & 0,58 & 0,9 & 1,12 & 1,24 & 1,32 & 1,41 & 1,45 & 1,49 & 1,51 & 1,48 & 1,56 & 1,57 & 1,59 \\
\hline
\end{tabular}

Kaynak: Saaty, 1980: 21.

Tutarlılık oranı değeri 0,10'dan küçük ise ilgili matris tutarlıdır ve kabul edilmektedir (Öner ve Ülengin, 1995:1109).

\section{AHP ANALIZİ BULGULARI}

Literatür taraması ile elde edilen kriterlerin ağırlıklarının analizinde öncelikli olarak banka kredi tahsis yetkililerinin görüşü ile kriterlerin puanlaması (1-9) istenmiştir. Bu yetkili kişiler ana kriter ve alt kriterler olmak üzere kriterleri puanlamıştır. Daha sonra bu değerlerin ortalaması ile karar matrisi oluşturulmuştur. İlk olarak analiz uygulaması ana kriterler üzerinde (müşteri ön kontrol, finansal yapısı, kurumsal kimlik ve yönetsel yapı ve istihbarat) gerçekleşmiştir. Daha sonra her kriterlerin alt kriterleri için karar matrisleri oluşturulmuştur. Daha sonrasında, tahsis yetkilisinin görüşlerinin ortalamaları alınarak elde edilen karar matrisinin tutarlılık düzeyi hesaplanmıştır. Tutarlılık düzeyinin 0,1 seviyesi civarında olması istenmektedir. Analiz sonucunda tüm matrislerin tutarlılık düzeyi bu değerin altındadır. Söz konusu kriterlerin önem düzeyleri, nihai sıralamaları ile tutarlılık seviyeleri aşağıdaki Tablo 6 da özetlenmiştir. 
Tablo 6. Ana Kriterlerin Önem Düzeyi, Tutarlılık Oranı ve Nihai Sıralama

\begin{tabular}{|c|c|c|}
\hline Ana Kriterler & Önem Düzeyi & Siralama \\
\hline Müşteri Ön Kontrol & 0,283137335 & 2 \\
\hline Finansal Yap1 & 0,538496892 & 1 \\
\hline Kurumsal Kimlik ve Yönetsel Yapı & 0,051579254 & 4 \\
\hline İstihbarat & 0,126786519 & 3 \\
\hline \multicolumn{3}{|l|}{ Tutarlilik orani: $0,049321198(C R<0,1)$} \\
\hline \multicolumn{3}{|c|}{ Alt Kriterler } \\
\hline 1. Müşteri Ön Kontrol & Önem Düzeyi & Siralama \\
\hline Firma Yetkilerinin Moralitesi & 0,113531906 & 4 \\
\hline Firma Ortaklarının Moralitesi & 0,11690119 & 3 \\
\hline Firmanın Faaliyet Konusunun Devamlılığ1 & 0,035870785 & 7 \\
\hline TCMB Memzuc Bilgisi & 0,076132595 & 5 \\
\hline İcra, Haciz, Vergi Borcu Sorgusu & 0,252967668 & 2 \\
\hline TCMB Karşılıksız Çek Kayıtları & 0,35772926 & 1 \\
\hline TCMB Protestolu Senet Kayıtları & 0,046866596 & 6 \\
\hline \multicolumn{3}{|l|}{ Tutarlılık oranı: 0,05632949 $(C R<0,1)$} \\
\hline 2. $\quad$ Finansal Yapt & Önem Düzeyi & Siralama \\
\hline Öz Sermaye Yapısı & 0,086919007 & 5 \\
\hline Likidite Yap1sı & 0,307582418 & 1 \\
\hline Net Satışlardaki Değişim & 0,073384208 & 6 \\
\hline Kısa Vadeli Borç / Toplam Borç Yapısı & 0,234261294 & 2 \\
\hline Dönem Net Karı & 0,152673993 & 3 \\
\hline Stoklardaki Değişim & 0,14517908 & 4 \\
\hline \multicolumn{3}{|l|}{ Tutarlılik orani: $0,06572177(C R<0,1)$} \\
\hline 3. Kurumsal Kimlik ve Yönetsel Yapı & Önem Düzeyi & Siralama \\
\hline Firmanın Faaliyet Süresi & 0,14763235 & 3 \\
\hline Firma Yöneticilerinin Sektör Deneyimi & 0,117049505 & 5 \\
\hline Firma Ortaklarının Sektör Deneyimi & 0,289735555 & 1 \\
\hline Firmanın Ortaklık Yapısı & 0,12605185 & 4 \\
\hline Firmanın Personel Sayısı & 0,066765888 & 6 \\
\hline İşletmenin Mülkiyet Durumu & 0,045156674 & 7 \\
\hline Teminat Durumu & 0,207608177 & 2 \\
\hline \multicolumn{3}{|l|}{ Tutarlılık oranı: $0,088053571(C R<0,1)$} \\
\hline 4. $\quad$ Istihbarat & Önem Düzeyi & Stralama \\
\hline İşletme Müşterilerinden İstihbarat & 0,081592389 & 5 \\
\hline Satıcılardan Elde Edile İstihbarat & 0,30529304 & 2 \\
\hline Sektördeki Rakip Firmalardan İstihbarat & 0,091149776 & 4 \\
\hline Çalıştığı Bankalardan istihbarat & 0,35998779 & 1 \\
\hline Sektörün Ekonomik Yapısı & 0,217344322 & 3 \\
\hline Kredi Talebinde Bulunan Müşterinin Ziyareti & 0,079754782 & 6 \\
\hline
\end{tabular}

Analiz sonuçlarına göre kredi tahsisi için göz önünde bulundurulan önem sırasıyla ana kriterler; finansal yapı, müşteri ön kontrol, istihbarat, kurumsal kimlik ve yönetsel yapı olarak sıralanmıştır. İlk ana kriter olan müşteri ön kontrol kriterine ilişkin alt kriterlerin önem düzeylerine göre sırası; TCMB karşılıksız çek bilgileri, icra, haciz ve vergi borcu kriteri, ortakların moralitesi, yöneticilerin moralitesi, TCMB memzuç (limit, risk ve kanuni takip) bilgisi, protestolu senet bilgisi ve faaliyet konusunun devamlılı̆̆ıdır. Finansal yapı ana kriterinin alt boyutları önem düzeylerine göre; likidite, borçlanma yapısı, dönem net kârı, stoklardaki değişim, öz sermaye ve net satışlardaki değişim olarak sıralanmıştır. Kurumsal kimlik ve yönetsel yapı kriterinin alt kriterlerinin önem düzeyleri sırasıyla; otakların deneyimi, teminat durumu, faaliyet süresi, ortaklık yapısı, yöneticilerin deneyimi, personel sayısı, işletmenin mülkiyet durumudur. Kredi tahsisinde göz önünde bulundurulan son ana kriter olan istihbarat kriterine ilişkin alt kriterlerin 
önem düzeyi sıralaması ise; bankalardan istihbarat, satıcılardan istihbarat, sektörün ekonomik yapısı, rakip firmalardan istihbarat, müşterilerden istihbarat, müşteri ziyareti olarak tespit edilmiştir.

Kredi tahsis aşamasında yararlanılan yukarıda açıklanan ön değerlendirme kriterleri ile bunların önem derecesine göre sıralanması bankalara otel işletmesinin ihtiyacı olan kredi limitini uygun teminat koşullarıyla kısa sürede tahsis edebilmelerini sağlayacaktır. Bankalardan kredi talebinde bulunan küçük ve orta ölçekli otel işletmelerin banka kredi limitlerinin revizesinde bankaların öncelikli dikkat ettiği kriterlerden biri finansal yapıdır. Dönem net kârılığının, net satışların yıllar itibariyle artış göstermesi, donuk alacaklarının olmaması vb., değerlendirmelerle ve aktarmaarındırmalarla kredi tahsis yetkili tarafından finansal yapısının güçlü olup olmadığı tespit edilebilir. Finansal yapısı güçlü olan otel işletmesinin ön kontrol incelemesi sonucunda işletme için olumsuzluk yaratacak karşılıksız çek bilgisinin olmaması, ödenmemiş herhangi bir vergi borcu, icra ve haciz bilgisine rastlanmaması, diğer bankalarla çalışmalarında kanuni takip veya kredi geri ödemelerinde problem yaşanmaması vb. otel işletmesinin kredi limitlerinin revizesinde kredi tahsisi olumlu yönde etkiler. Ayrıca istihbarat kriteri ile işletmenin bugünü, yarını ve geleceği hakkında bilgi sahibi olunmasını işletmenin faaliyetlerine sağlıklı bir şekilde devamlılı̆̆ını ölçmede önemlidir. Kurumsal ve yönetsel yapısı ise sektördeki rakiplerine göre konumunu, işletmenin faaliyetlerindeki profesyonelliğini, değişen koşullara uyum sağlayabilme kabiliyetine karar vermede bankalara bilgi sağlamış olacaktır. Tüm bu kriterlerin olumlu olması kredi tahsis süreçlerinin hemen sonuçlanmasına, kredi limitlerin hızlı bir şekilde revize edilmesine, limitlerin talep edildiği gibi onaylanmasına ve daha kolay tahsis şartlarının belirlenmesine olanak sağlaması açısından önemlidir.

\section{SONUÇ ve ÖNERILER}

Kredi talebi işlemlerinin başlamasından kredi limitlerinin oluşturulmasına kadar gerçekleştirilen işlemler kredi tahsis süreçlerini oluşturur. Kredi değerlendirme, kredi tahsis ve kredi yönetimi süreçleri bankaların faaliyetlerini verimli bir şekilde yürütebilmeleri açısından hızlı, dikkatli ve doğru bir şekilde yapılmaktadır. Kredi talepleri incelenirken kredi talebinde bulunan müşteriye ait banka ve piyasa istihbaratının doğru yapılması çok iyi araştııılması ve mali verilerinin detaylı bir şekilde derinlemesine incelenmesi gerekir. Kredi tahsis süreci kredi talebinde bulunan müşterinin ziyaret edilmesi, tahsis aşamasında gerekli olan evrakların temin edilmesi, ön kontrol süreciyle müşterinin moralitesinin derinlemesine araştırılması, mali analizler, piyasa istihbaratının yapılması, tahsis komitesi ile kredi talebinin değerlendirilip bir karar varılması aşamalarından oluşmaktadır. Tüm bu aşamalar yeni kredi talebi, mevcut kredi limitlerinin revize edilmesi ya da limit artışı talepleri için gerçekleştirilir. Kredi komitesi kararı ile işletmelerin kredi talebi limit artışı ile revize edilebilir, eski limitlerle çalışılması uygun bulunabilir ya da kredi teklifi ret edilebilir. Kredi komitesi söz konusu bu kararları ön değerlendirme kriterleri ve bankanın kredi politikaları çerçevesinde almaktadır. Bu çalışmanın amacı, bankaların küçük ve orta ölçekteki otel işletmelerinin kredi limitlerini revize ederken tahsis aşamasında göz önünde bulundurdukları ön değerlendirme kriterlerinin neler olduğunun açıklamak ve bu kriterlerin önem derecesini belirlemektir. Bu amaçla müşteri ön kontrol kriteri, finansal yapı kriteri, istihbarat kriteri ile kurumsal kimlik ve yönetsel yapı kriteri olmak üzere 4 ana kriter ve bu ana kriterlere ait 26 alt kriterleri seçilmiş ve bu kriterler AHP yöntemi analiz edilmiştir. Kredi tahsis aşamasında yararlanılan tahsis ön değerlendirme kriterleri bankalara firmaların ihtiyacı kadar kredi limitini uygun teminat koşulları ile tahsis etmeleri için önemli finansal bilgiler içermektedir. Ayrıca ön değerlendirme kriterlerinden elde edilen bilgilerle kredi tahsis komitesi bankanın ne 
kadarlık bir kredi riskini üstlenilmesi gerektiği, kredinin hangi teminat koşulları ve tahsis şartları ile verilmesi gerektiği konusunda kararlar alabilmektedir.

Analiz sonuçlarına göre küçük ve orta ölçekli kredi tahsisi için dikkate alınan ana kriterlerin önem sırası; finansal yapı, müşteri ön kontrol, istihbarat, kurumsal kimlik ve yönetsel yapı sıralanmıştır. Müşteri ön kontrol ana kriterine yönelik alt kriterlerin önem sırası; karşılıksız çek bilgileri, icra, haciz ve vergi borcu kriteri, işletme ortaklarının moralitesi, yöneticilerin moralitesi ile TCMB memzuç bilgisi en önemli kriterler olarak belirlenirken protestolu senet bilgisi ve faaliyet konusunun devamlılığı en az önemlilik kriteri olarak belirlenmiştir. Değerlendirme ana kriterlerinden finansal yapı kriterine ait alt kriterlerin önem düzeyi sıralaması ise likidite, kısa vadeli borçlar/toplam borçların yapısı, dönem net kârı, stoklardaki değişim, öz sermaye ve net satışlardaki değişim olarak belirlenmiştir. Kredi tahsis ön değerlendirme kriterlerinden kurumsal kimlik ve yönetsel yapı alt kriterlerinin önem düzeyleri incelendiğinde; otakların deneyimi, teminat durumu, faaliyet süresi, ortaklık yapısı, en önemli kriterlerden yöneticilerin deneyimi, personel sayısı, işletmenin mülkiyeti ise daha az önemli kriter olarak belirlenmiştir. Kredi tahsisinde göz önünde bulundurulan istihbarat kriterine göre alt kriterlerin önem düzeyi sıralaması; bankalardan, satıcılardan yapılan istihbarat, sektörün ekonomik yapısı, rakip firmalardan, müşterilerden istihbarat en önemli kriterler olarak belirlenirken müşteri ziyaretinin ise en az önem derecesine sahip olduğu sonucuna ulaşılmıştır.

Analiz sonuçlarında kredi tahsis ön değerlendirme kriterlerinin önem derecesinin ve ağırlıklarının belirlenmesi ile bankalar kredi taleplerini değerlendirirken işletmelerin gerçek kredi ihtiyacını kolayca belirleyebilecek, işletmelere tahsis edilecek kredinin hangi şartlarla verilebileceğini kolayca tespit edebilecek, kredi limitlerine uygun hangi tür teminatların alınması gerektiğine karar verebilecek ve bankanın ne kadar risk üstlenmesi gerektiği konusunda daha sağlam kararlar verebilecektir. Aynı zamanda kredi talep eden otel işletmeleri de bu değerlendirme kriterlerinin önem sırası ile gerekli aksiyonları alabilecektir. Kredi talebinde bulunan küçük ve orta ölçekli otel işletmelerin kredilerinin istedikleri şartlarda ve limitlerde onaylanması için bu önem sırasına göre belirlenmiş değerlendirme kriterlerindeki zayıf ve eksik yönlerini geliştirmelerine, olumsuzluk oluşturan durumları ise düzeltme konusundaki çabalarını artırıcı faaliyetlerde bulunmalarına neden olabilecektir. Tüm bu ana değerlendirme kriterlerinin ve alt kriterler ile ilgili incelemelerin olumlu sonuçlanması kredi tahsis süreci sürelerinin kısalmasına, kredi limitlerin daha hızlı bir şekilde sonuçlanmasına, limitlerin ise talep edildiği gibi onaylanmasına olanak sağlayacaktır. Ayrıca bankaların kredi değerlendirilmesinde özellikle karar verme sürecindeki hataların önüne geçilmesi konusunda yol göstericidir., AHP Yöntemi kullanılarak yapılan karar analizinin sonuçları ile muhtemel bir kredi borçlunun gereklilikleri karşılayıp karşılamayacağını ölçmede doğru kararın belirlenmesinde yardımcı olabilecektir. Bu durum kredili müşterinin memnuniyeti artırmaya ve bankaların müşterilerine en iyi hizmeti sunmasina yardımcı olur

Literatür incelendiğinde çalışmaların genellikle bankalardan talep edilen kredilerin değerlendirme aşamaları ile bankaların bireysel, küçük ve orta büyüklükteki işletmeler ve ticari işletmelere tahsis edilen kredilerin değerlendirme kriterleri üzerinde yapılan araştırmaların olduğu görülmektedir. Bu bağlamda söz konusu çalışmada küçük ve orta büyüklükteki özellikle otel işletmelerinin örnek olarak seçilmesi, bu işletmelerin kredi limitlerinin revizesinin tercih edilmiş olması ve bu süreçte banka kredi tahsis ön değerlendirme kriterlerinin gerekliliğinin vurgulanması sonucunda çalışmanın literatüre katkı sağlayacağı düşünülmektedir. Ayrıca çalışmanın farklı sektörlere ilişkin yapılacak çalışmalarda da kredi tahsis ön değerlendirme kriterlerinin kapsamı genişletilerek uygulanması ve çalışmanın farklı yöntemlerle de analiz edilebilmesi açısından yeni araştırmalar için faydalı olacağı söylenebilir. 


\section{KAYNAKÇA}

Akkaya, G. C. ve Demireli, E. (2010). Analitik Hiyerarşi Süreci ile Kredi Derecelendirme Analizi Üzerine Bir Model Önerisi, Çukurova Üniversitesi, Sosyal Bilimler Enstitüsü Dergisi, 19(1), 319-335.

Aouam,T., Lamrani, H., Aguenaou, S. and Diabat, A. (2009). A Benchmark Based AHP model for Credit Evaluation, International Journal of Applied Decision Sciences , 2(2),151-166.

Atan, M. ve Maden, U., (2005). Bireysel ve Kurumsal Kredibilitenin Analitik Hiyerarşi Süreci ile Çözümlenmesi, 4. İstatistik Kongresi, İstatistik Mezunları Derneği ve Türk İstatistik Derneği, 8-12 Mayıs, Belek, Antalya.

Büyükçelebi, B., Coşkun, M. (2015). Ticari Kredi Taleplerinin Değerlendirilmesi Açısından Mevduat Bankaları ile Katılım Bankalarının Karşılaştırılması, Adıyaman Üniversitesi Sosyal Bilimler Enstitüsü Dergisi, 8 (21), 1004 -1024.

Chen, L.-H., and Chiou T.-W. (1999). A Fuzzycredit-rating Approach for Commercial Loans: a Taiwan Case. Omega, 27(4), 407-419.

Çetiner, E. (2002). Konaklama İşletmelerinde Muhasebe Uygulamaları, Ankara: Gazi Kitabevi.

Eren, A., Ilgaz, B. ve Karapınar, A. (2020). Bankaların Konaklama İşletmelerine Kredi Tahsis Kriterlerinin Belirlenmesi ve Bir Model Önerisi, Ankara Hacı Bayram Üniversitesi İ̈BF Dergisi, 23(1), 187-206.

Erpolat, S. (2011). Ticari Firma Kredi Taleplerinin Değerlendirilmesinde AHY ile Farklı Bulanık Sıralama Yöntemlerinin Denendiği BAHY'nin İncelenmesi, Öneri Dergisi, 9 (36), 213-235.

Ferreira, F. A. F., Santos, S. P., and Dias, V. M. C. (2014). An AHP-Based Approach to Credit Risk Evaluation of Mortgage Loans. International Journal of Strategic Property Management, 18(1), 38-55.

Fernando, E. and Siagian, P. (2020). Proposal to use the Analytic Hierarchy Process Method Evaluate Bank Credit Submissions. Procedia Computer Science (179), 232-241.

Girginer, N. (2008). Ticari Kredi Taleplerinin Değerlendirmesine Çok Kriterli Yaklaşım: Özel ve Devlet Bankası Karşılaştırması, Muhasebe ve Finansman Öğretim Üyeleri Bilim ve Araştırma Derneği (MUFAD), Muhasebe ve Finansman Dergisi, (37), 132 - 142.

Hosseini, M. H. and Keshavarz, E. (2017). Using Fuzzy AHP and Fuzzy TOPSIS for Strategic Analysis Measurement of Service Quality in Banking Industry, International Journal of Applied Management Science (IJAMS), 9(1), 44-80.

İç, Y.T. ve Yurdakul, M. (2000). Analitik Hiyerarşi Süreci (AHS) Yöntemini Kullanan Bir Kredi Değerlendirme Sistemi, Gazi Üniversitesi Mühendislik Mimarlık Fakültesi Dergisi 15(1), 1-14.

Karadeniz, E., Koşan, L., ve Geçkin, E. (2018). Kobi Kapsamındaki Otel İşletmelerinin Finansal Sorunları: Kars ve Erzurum İllerinde Bir Araştırma, Seyahat ve Otel İşletmeciliği Dergisi, 15 (2), 302 $-319$.

Karakış, E. ve Göktolga, Z.Y. (2017). Bankaların Ticari Kredi Verme Davranışlarının Bulanık Ahp ve Bulanık Topsıs ile İncelenmesi, C.Ü. İktisadi ve İdari Bilimler Dergisi 18(2), 75-98.

Kocameşe, K. (2006). Küçük İşletmelerin Kredi Taleplerinin Değerlendirilmesinde Kredi Derecelendirme Sistemi Uygulaması, İstanbul Üniversitesi, Sosyal Bilimler Enstitüsü, İşletme Ana Bilim Dalı, Yüksek Lisans Tezi, İstanbul.

KOSGEB. (2018). Küçük ve Orta Büyüklükteki İşletmelerin Tanımı, Nitelikleri ve Sınıflandırılması Hakkında Yönetmelik. Ankara. 
Küçükaltan, K. D. ve Eskin, İ. (2008), Türkiye'deki Otel İşletmelerine Bir Finansman Modeli Olarak Teşvikler, Trakya Üniversitesi Sosyal Bilimler Dergisi, 10(2), 158-172.

Öner, A. ve Ülengin, F. (1995). Silah Seçiminde AHP Yaklaşımı. Kara Harp Okulu, I. Sistem Mühendisliği ve Savunma Uygulamaları Sempozyumu, Bildiriler-II, 1109-1122.

Saardchom, N. (2012) Credit Scoring Model by Analytic Hierarchy Process AHP, Global Review of Accounting and Finance, 3(2), 58-73.

Pekkaya, M. ve Zilifli, V. (2016). Bankaların Ticari Kredi Değerlendirme Aşamasında Dikkate Aldıkları Kriterlerin Önem Derecelerinin Belirlenmesi, Uluslararası Yönetim İktisat ve İşletme Dergisi, (Özel Sayı), 201-210.

Saaty, T. L. (1990). How to Make A Decision: The Analytic Hierarchy Process, European Journal of Operational Research, 48, 9-26.

Sekreter M. S., Akyüz, G. ve Çetin E.İ. (2004). Şirketlerin Derecelendirilmesine İlişkin Bir Model Önerisi: Gıda Sektörüne Yönelik Bir Uygulama, Akdeniz Üniv. İ.I.B.F. Dergisi, (8), 139-155.

Vargas, Luis G. (1990). An Overview of the Analytic Hierarchy Process and It's Applications. European Journal of Operational Research, 48(1), 2 - 8.

Yazıcı, M. (2010). Bankacılıkta Kredi Tahsisi, 1. Baskı, Seçkin Yayıncılık, Ankara.

Yaralığlu K. (1999). Analitik Hiyerarşi Proses Yöntemi ile Genel Seçim Sonuçlarının Tahminlemesi, IV. Ulusal Ekonometri ve İstatistik Sempozyumu. 